\title{
Polymorphism of the DNA repair genes RAD51 and $X R C C 2$ in smoking- and drinking-related laryngeal cancer in a Polish population
}

\author{
Hanna Romanowicz-Makowska ${ }^{1}$, Beata Smolarz ${ }^{1}$, Marzena Gajęcka², Katarzyna Kiwerska², \\ Malgorzata Rydzanicz², Dariusz Kaczmarczyk³ ${ }^{3}$ Jurek Olszewski ${ }^{4}$, Krzysztof Szyfter ${ }^{2}$, Janusz Błasiak ${ }^{5}$, \\ Alina Morawiec-Sztandera ${ }^{3}$
}

\author{
1Laboratory of Molecular Genetics, Department of Pathology, Institute of Polish Mother's \\ Memorial Hospital, Lodz, Poland \\ 2Institute of Human Genetics, Polish Academy of Sciences, Poznan, Poland \\ ${ }^{3}$ Department of Head and Neck Cancer, Medical University of Lodz, Poland \\ ${ }^{4}$ Department of Otolaryngology, Medical University of Lodz, Poland \\ ${ }^{5}$ Department of Molecular Genetics, University of Lodz, Poland
}

Submitted: 11 March 2011

Accepted: 17 July 2011

Arch Med Sci 2012; 8, 6: 1065-1075

DOI: 10.5114/aoms.2012.32417

Copyright (c) 2012 Termedia \& Banach

\author{
Corresponding author: \\ Beata Smolarz MD, PhD \\ Laboratory of Molecular \\ Genetics \\ Department of Pathology \\ Institute of Polish \\ Mother's Memorial Hospital \\ 281/289 Rzgowska St \\ 93-338 Lodz, Poland \\ Phone: +48 422712071 \\ E-mail: smolbea@wp.pl
}

\begin{abstract}
Introduction: Cigarette smoke and alcohol can generate reactive oxygen species, which may induce DNA double-strand breaks (DSBs), the most serious DNA lesion. In humans, DSBs are repaired mainly by non-homologous end joining and homologous recombination repair (HRR). Several polymorphisms in the DNA repair gene have been extensively studied in the association with various human cancers. In the present work we investigated the association between polymorphisms of two HRR genes, XRCC2 and RAD51, and tobacco- and alcoholrelated larynx cancer in a Polish population.

Material and methods: Two polymorphisms of the XRCC2 gene, $-41657 C>T$ (rs718282) and 31479G $>\mathrm{A}$ (rs3218536), as well as one polymorphism of the RAD51 gene, $-135 \mathrm{G}>\mathrm{C}$ ( $\mathrm{rs1801320}$ ), were investigated by PCR-RFLP in 253 patients with larynx cancer and 253 age- and sex-matched non-cancer controls.

Results: Analysis of the gene-smoking and-drinking interactions revealed a weak association between larynx cancer and the $-41657 \mathrm{C}>T$ polymorphisms of the XRCC2 gene among the moderate alcohol drinkers. The $C$ allele of the $-135 \mathrm{G}>C$ polymorphism of RAD51 increased cancer risk in the smoker group. Increased risk was also found for heavy drinkers. Additionally, there were no significant differences between distributions of genotypes in subgroups assigned to different TNM stages and grades.

Conclusions: The results indicated that the $-135 \mathrm{G}>\mathrm{C}$ polymorphism of the RAD51 gene may be associated with smoking- and drinking-related larynx cancer in Poland.
\end{abstract}

Key words: RAD51, XRCC2, laryngeal cancer, polymorphism.

\section{Introduction}

Larynx cancer is strongly associated with smoking and high alcohol consumption, as well as occupational and environmental exposure to carcinogens [1-3]. Cigarette smoke can generate reactive oxygen species, which are capable of inducing DNA double-strand breaks (DSBs) [4], 
H. Romanowicz-Makowska, B. Smolarz, M. Gajęcka, K. Kiwerska, M. Rydzanicz, D. Kaczmarczyk, J. Olszewski, K. Szyfter,

J. Błasiak, A. Morawiec-Sztandera

the most serious DNA damage, which, if not repaired or misrepaired, may result in genomic instability, cancer transformation or cell death [5-7].

Double-strand breaks are repaired by two major mechanisms: homologous recombination repair (HRR) and nonhomologous end joining (NHEJ) $[8,9]$.

RAD51 is a protein playing a central role in HRR through direct interaction with XRCC2, XRCC3, BRCA1, BRCA2 and other proteins to form a complex essential for the repair of DSBs and cross-links in DNA [10].

The RAD51 gene has been mapped to chromosome $15 q 14-15$ and is highly polymorphic. The involvement of RAD51 in DNA repair determines its potential role in maintaining genetic stability, which is disturbed in cancer. Therefore the problem of genetic variability of the RAD51 gene in cancer is worth studying. A substitution $\mathrm{G} / \mathrm{C}$ at position 135 in the 5' untranslated region (UTR) of the RAD51 gene (the 135 G/C 5' UTR polymorphism) has been reported as a possible factor to affect $R A D 51$ mRNA stability $[11,12] .-135 G>C$ polymorphism of RAD51 is located in the regulatory element of the RAD51 promoter and is suggested to be associated with messenger RNA expression. A study of women matched for BRCA1 mutation revealed that the $C$ allele of this polymorphism is associated with a 2-fold lowering of breast and ovarian cancer risk as compared with the wildtype $\mathrm{G}$ allele [13]. The results of several previous studies suggested that RAD51-135G >C polymorphism might be used as a predictive factor of precancerous lesions for head and neck cancer in a Polish population [14].

The XRCC2 gene, located at 7q36.1, is an essential part of the homologous recombination repair pathway and a functional candidate for involvement in cancer progression [15]. Common variants within $X R C C 2$, including single nucleotide polymorphisms (SNPs) in exon 3 (Arg188His, $\mathrm{R} 188 \mathrm{H}, \mathrm{rs} 3218536$ or $31479 \mathrm{G}>\mathrm{A}$ ), have been identified as potential cancer susceptibility loci in recent studies, although association results are controversial. The Arg188His polymorphism has been proposed to be a genetic modifier for smoking-related pancreatic cancer and was associated with an increased risk of pharyngeal cancer and oral cancer risk [16-18]. The $188 \mathrm{His}$ allele of this polymorphism may be associated with a significantly increased risk of breast cancer, but not with bladder cancer, colorectal adenoma, or skin cancer [19-22].

In the present study the association between the $-41657 \mathrm{C}>\mathrm{T}$ and $31479 \mathrm{G}>\mathrm{A}$ polymorphisms of the $X R C C 2$ gene and the $-135 \mathrm{G}>C$ polymorphism of the RAD51 gene and smoking- and drinking-related larynx cancer was investigated.

\section{Material and methods}

\section{Patients}

Blood samples were obtained from 253 patients: 194 men and 59 women with larynx cancer (squamous cell carcinoma) treated in the Department of Head and Neck Cancer, Medical University of Lodz, Lodz, Poland and the Department of Otolaryngology, Medical University of Poznan, Poland in 2005-2009 and 253 cancer-free age- and sexmatched controls. The patients ranged in age from 48 to 86 years (median: 63 years, mean \pm SD: 63.9 $\pm 8.4)$. There were 138 cases $(55 \%)$ of grade 1 , 104 cases (41\%) of grade 2, and 11 cases (4\%) of grade 3 in total. According to TNM staging there were 60 cases $(24 \%)$ of stage I, 33 cases $(13 \%)$ of stage II, 113 cases (45\%) of stage III, 41 cases $(16 \%)$ of stage IVA, and 6 cases $(2 \%)$ of stage IVB. The study was approved by the Bioethics Committee of the Medical University of Lodz and each patient gave written consent.

\section{DNA isolation}

Peripheral blood lymphocytes (PBLs) were isolated by centrifugation in a density gradient of Histopaque-1077 (15 min, 280 g). Genomic DNA was isolated from PBLs by phenol/chloroform extraction and proteinase $\mathrm{K}$ digestion. The final samples were kept in Tris-EDTA buffer, $\mathrm{pH} 8$, at $-20^{\circ} \mathrm{C}$ until use.

\section{PCR-RFLP}

The PCR-restriction fragment length polymorphism method (PCR-RFLP) was used to detect the genotypes of the $-41657 C>T$ and $-135 G>C$ polymorphisms as described previously $[23,24]$. The 31479G $>$ A polymorphism was determined using the primers $5^{\prime}$-AGTTGCTGCCATGCCTTACA-3' and 5'-TGTAGTCACCCATCTCTCTGC-3' at a final $\mathrm{Mg}^{2+}$ concentration of $1.5 \mathrm{mM}$ and annealing temperature $58^{\circ} \mathrm{C}$. The $290 \mathrm{bp} \mathrm{PCR}$ product was digested overnight with $3 \mathrm{U}$ of the restriction enzyme Hphl. The homozygous A/A genotype produced $148 \mathrm{bp}$ and $142 \mathrm{bp}$ fragments, whereas the heterozygous genotype G/A produced three fragments of $290 \mathrm{bp}$, $148 \mathrm{bp}$ and $142 \mathrm{bp}$, and the homozygous G/G genotype abolished the restriction site of $\mathrm{Hphl}$ and resulted in one 290 bp fragment. Restriction fragments were analyzed on an $8 \%$ polyacrylamide gel stained with ethidium bromide.

\section{Statistical analysis}

For each polymorphism, departure of the genotype distribution from that expected from HardyWeinberg equilibrium was assessed using the standard $\chi^{2}$ test or Fisher's exact test (for $N \leq 10$ ). Genotype frequencies in cases and controls were compared by $\chi^{2}$ tests. The genotype-specific risks 
were estimated as odds ratios (ORs). In all cases wild type genotype served as a reference group.

\section{Results}

\section{$X R C C 2$ and $R A D 51$ gene polymorphisms}

Table I displays the distribution of genotypes and frequency of alleles of the -41657 C $>T, 31479 G>A$ and $-135 G>C$ polymorphisms in patients with larynx cancer and controls. All distributions of genotypes and alleles were in Hardy-Weinberg equilibrium. We did not find any significant difference in genotype or allele frequencies in patients with cancer and controls $(p>0.05)$.

Table II shows the haplotype distribution of $X R C C 2$. The haplotype analysis according to wild

Table I. Distribution of genotypes and odds ratios (OR) of the $31479 \mathrm{G}>\mathrm{A}$ and $41657 \mathrm{C}>\mathrm{T}$ polymorphisms of the $X R C C 2$ gene and the $-135 \mathrm{G}>\mathrm{C}$ polymorphism of the RAD51 gene in patients with larynx cancer and controls

\begin{tabular}{|c|c|c|c|c|}
\hline Genotype & Patients $(N=253), n(\%)$ & Controls $(N=253), n(\%)$ & OR $(95 \% \mathrm{Cl})^{\mathrm{a}}$ & Value of $p^{b}$ \\
\hline \multicolumn{5}{|c|}{$31479 \mathrm{G}>\mathrm{A} X R C C 2$} \\
\hline $\mathrm{G} / \mathrm{G}$ & $230(90.9)$ & $240(94.9)$ & 1.00 Ref. & \\
\hline $\mathrm{G} / \mathrm{A}$ & $22(8.7)$ & $13(5.1)$ & $1.76(0.86-3.59)$ & 0.157 \\
\hline$A / A$ & $1(0.4)$ & 0 & $\mathrm{NE}$ & \\
\hline$G / A+A / A$ & $23(9.1)$ & $13(5.1)$ & $1.84(0.91-3.73)$ & 0.119 \\
\hline G & $482(95)$ & $493(97)$ & 1.00 Ref. & \\
\hline A & $24(5)$ & $13(3)$ & $1.88(0.95-3.75)$ & 0.093 \\
\hline \multicolumn{5}{|c|}{$-41657 C>T$ XRCC2 } \\
\hline $\mathrm{C} / \mathrm{C}$ & $88(34.8)$ & $75(29.6)$ & 1.00 Ref. & \\
\hline $\mathrm{C} / \mathrm{T}$ & $148(58.5)$ & $168(66.4)$ & $0.75(0.51-1.09)$ & 0.165 \\
\hline $\mathrm{T} / \mathrm{T}$ & $17(6.7)$ & $10(4.0)$ & $1.44(0.63-3.35)$ & 0.507 \\
\hline$C / T+T / T$ & $165(65.2)$ & $178(70.4)$ & $0.79(0.54-1.14)$ & 0.254 \\
\hline C & $324(64)$ & $318(63)$ & 1.00 Ref. & \\
\hline $\mathrm{T}$ & $182(36)$ & $188(37)$ & $0.95(0.74-1.23)$ & 0.740 \\
\hline \multicolumn{5}{|c|}{$-135 G>C$ RAD 51} \\
\hline $\mathrm{G} / \mathrm{G}$ & $174(68.8)$ & $190(75.1)$ & 1.00 Ref. & \\
\hline $\mathrm{G} / \mathrm{C}$ & $69(27.3)$ & $58(22.9)$ & $1.29(0.87-1.94)$ & 0.145 \\
\hline $\mathrm{C} / \mathrm{C}$ & $10(3.9)$ & $5(2.0)$ & $2.18(0.73-6.51)$ & 0.242 \\
\hline $\mathrm{G} / \mathrm{C}+\mathrm{C} / \mathrm{C}$ & 79 (31.2) & $63(24.9)$ & $1.37(0.92-2.02)$ & 0.138 \\
\hline G & 417 (82) & $438(86)$ & 1.00 Ref. & \\
\hline C & 89 (18) & 68 (14) & 1.37 (0.97-1.94) & 0.082 \\
\hline
\end{tabular}

$N E$ - not estimated, a Crude odds ratio (OR), $95 \% \mathrm{Cl}$ - confidence interval at $95 \%,{ }^{b} \chi^{2}$

Table II. Haplotype distribution and frequencies of XRCC2 gene polymorphisms in larynx cancer patients and controls

\begin{tabular}{|c|c|c|c|c|}
\hline Haplotypes & Patients $(N=253), n(\%)$ & Controls $(N=253), n(\%)$ & OR $(95 \% \mathrm{Cl})^{a}$ & Value of $p^{b}$ \\
\hline \multicolumn{5}{|c|}{ XRCC2-31479-41657 } \\
\hline $\mathrm{G} / \mathrm{G}-\mathrm{C} / \mathrm{C}$ & 79 (31.2) & $74(29.2)$ & 1.00 Ref. & \\
\hline $\mathrm{G} / \mathrm{A}-\mathrm{C} / \mathrm{C}$ & 9 (3.6) & $3(1.2)$ & $2.81(0.73-10.78)$ & 0.207 \\
\hline $\mathrm{A} / \mathrm{A}-\mathrm{C} / \mathrm{C}$ & 0 & 0 & NE & \\
\hline $\mathrm{G} / \mathrm{G}-\mathrm{C} / \mathrm{T}$ & $136(53.8)$ & $158(62.4)$ & $0.81(0.54-1.19)$ & 0.327 \\
\hline $\mathrm{G} / \mathrm{A}-\mathrm{C} / \mathrm{T}$ & $13(5.1)$ & $8(3.2)$ & $1.52(0.59-3.88)$ & 0.516 \\
\hline $\mathrm{A} / \mathrm{A}-\mathrm{C} / \mathrm{T}$ & $1(0.4)$ & 0 & NE & \\
\hline $\mathrm{G} / \mathrm{G}-\mathrm{T} / \mathrm{T}$ & $15(5.9)$ & $8(3.2)$ & $1.75(0.70-4.38)$ & 0.319 \\
\hline $\mathrm{G} / \mathrm{A}-\mathrm{T} / \mathrm{T}$ & 0 & $2(0.8)$ & NE & \\
\hline $\mathrm{A} / \mathrm{A}-\mathrm{T} / \mathrm{T}$ & 0 & 0 & NE & \\
\hline
\end{tabular}

$N E$ - not estimated, a Crude odds ratio (OR), $95 \% \mathrm{Cl}$ - confidence interval at $95 \%,{ }^{b} \chi^{2}$ 
type of G31479G-C41657C showed a lack of association with laryngeal cancer.

In order to evaluate whether the polymorphisms were associated with the progression of larynx cancer, individuals were categorized into groups according to the cancer staging system of the TNM Classification of Malignant Tumours.

We did not find any association of the XRCC2 and $R A D 51$ polymorphisms in the patient group with cancer progression assessed by TNM staging $(p>0.05)$ (data not shown).

There were no significant differences between distributions of genotypes in subgroups assigned to a particular histological grade $(p>0.05)$.

\section{Gene-smoking and gene-alcohol drinking interaction}

All patients and controls were divided into four groups: non-smokers (never), subjects smoking 10 cigarettes per day for 10 years (ever), those smoking 20 cigarettes per day for 20 years (moderate), and those smoking 20 cigarettes per day for 30 years (heavy). Among patients, 110 were ever smokers, 41 were moderate smokers, and 79 were heavy smokers. There were 76 ever, 31 moderate and 23 heavy smokers in the control group. The group of never smokers comprised 123 controls and 32 patients.

We investigated the relationship between smoking and the risk for larynx cancer, independent of genotype. We compared cancer patients and controls according to their smoking habits. Smoking significantly increased the risk of larynx cancer. Individuals who declared that they were moderate smokers had a slightly smaller odds ratio $(O R=$ 8.57; $95 \% \mathrm{Cl}: 5.19-13.98)$ than individuals who declared that they were former smokers (ever group) (OR = 9.89; 95\% Cl: 6.84-14.28). Alcohol consumption also significantly increased the risk of larynx cancer. However, the effect of alcohol consumption was not so strong as smoking; for example, heavy smokers had OR almost five times greater $(O R=29.10 ; 95 \% \mathrm{Cl}: 17.37-49.45)$ than heavy drinkers $(\mathrm{OR}=6.26 ; 95 \% \mathrm{Cl}$ : 3.58-11.03).

Table III shows the genotype distribution in cases and controls. Odds ratio analysis showed a statistically significant positive association of larynx cancer risk and smoking status for carriers of the $C$ allele of the $-135 \mathrm{G}>\mathrm{C}$ polymorphism of the RAD51 gene. The risk of larynx cancer increased significantly in heavy smokers.

We also investigated the association between the polymorphisms and alcohol consumption (Table IV). Drinking habits were categorized in terms of non-drinking, moderate and heavy drinkers. We defined "moderate" drinking as 1-2 drinks/day, and "heavy" drinking as 3 or more drinks/day. In the control group there were 112 non-drinkers,
121 moderate and 20 heavy drinkers. Among patients, 60 were non-drinkers, 150 moderate and 43 heavy drinkers.

We found a statistically significant increase in risk of laryngeal cancer in the group of heavy alcohol drinkers carrying the $C$ allele of the $-135 \mathrm{G}>\mathrm{C}$ polymorphism of the RAD51 gene. An observed increased risk of larynx cancer associated with this polymorphism for moderate alcohol drinkers was not statistically significant. We found a positive association between the risk of larynx cancer and the $C / T$ genotype of the $-41657 C>T$ polymorphism of the $X R C C 2$ gene in moderate drinkers.

The findings indicated that a statistically significant increased risk of head and neck cancer in nondrinkers was associated with heterozygous G31479A and the combined G31479A-A31479A genotype. The variant $A$ allele of $X R C C 2$ increased cancer risk in this group (Table IV).

\section{Discussion}

An attempt was undertaken in the present study to determine whether single nucleotide polymorphisms (SNPs) in the DNA repair pathway (XRCC2 $-41657 \mathrm{C}>\mathrm{T}, X R C C 231479 \mathrm{G}>\mathrm{A}$, and $R A D 51-135 \mathrm{G}>\mathrm{C}$ ) were associated with the risk of smoking- and drinking-related larynx cancer.

Tobacco smoking and alcohol drinking generate oxidative DNA damage which may contribute to larynx cancer. Tobacco smoke contains high quantities of chemical carcinogens, such as polycyclic aromatic hydrocarbons, aromatic amines, $N$-nitroso compounds and reactive oxygen species (ROS). These chemicals can form bulky adducts after activation by specific enzymes [25], and can induce a variety of oxidative damage [25-28].

A causal association has been established between alcohol consumption and cancers of the oral cavity, larynx, liver, colon, rectum, esophagus, pancreas and lung as well as breast cancer in women. The effect of alcohol can be modulated by polymorphisms in genes encoding enzymes for ethanol metabolism (alcohol dehydrogenases, aldehyde dehydrogenases, and cytochrome P450 2E1), folate metabolism, and DNA repair [29, 30]. Alcohol consumption is increasing in many countries and is an important cause of cancer worldwide [31].

Several studies have reported that the genes involved in DNA repair and in the maintenance of genome integrity play a crucial role in protecting against mutations that lead to cancer. Single nucleotide polymorphisms have been identified in several DNA repair genes, such as XRCC2 and $R A D 51$, but the influence of specific genetic variants on repair phenotype and cancer risk has not yet been clarified. The polymorphisms chosen for this study have been shown to have functional sig- 


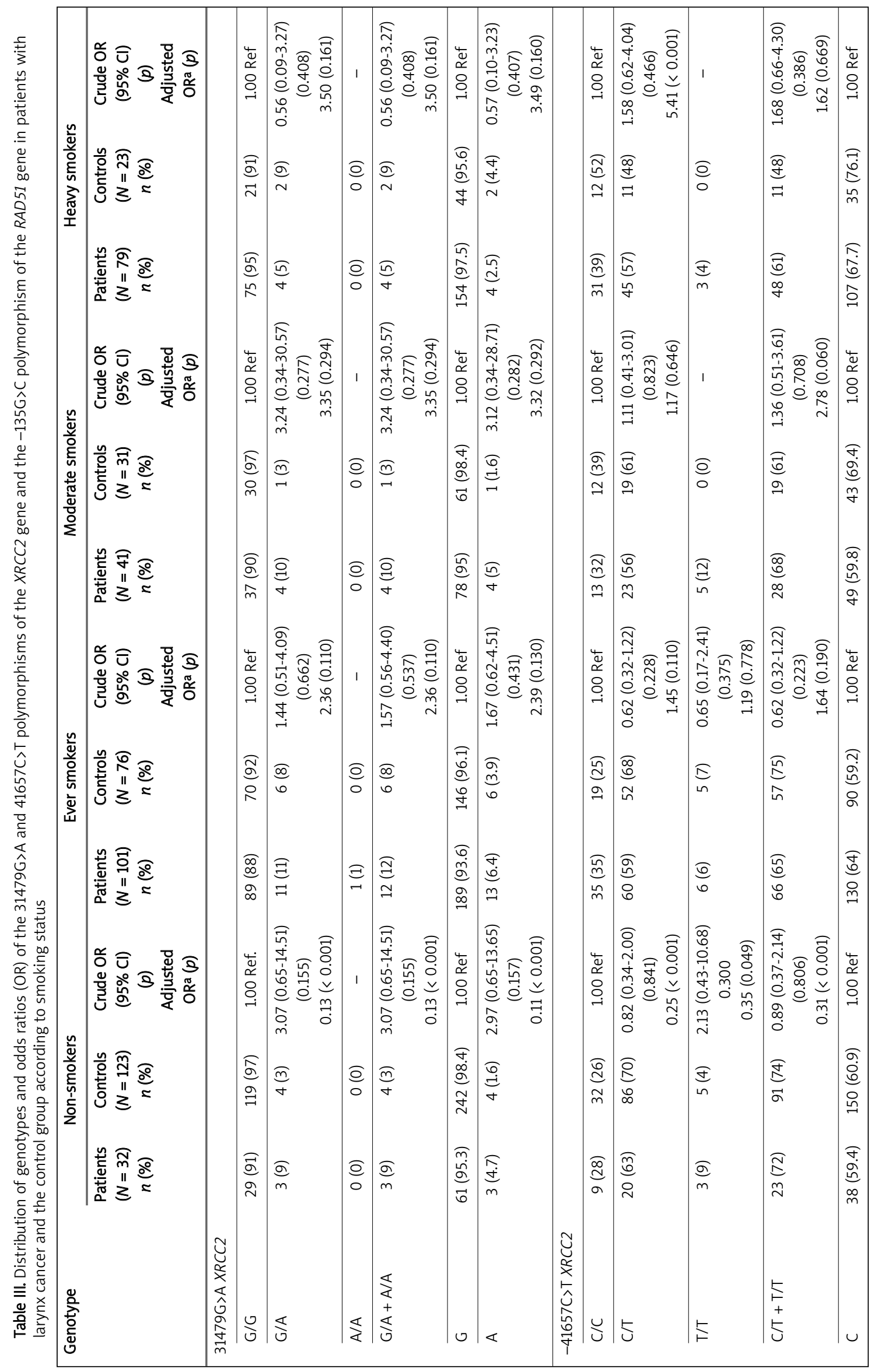


H. Romanowicz-Makowska, B. Smolarz, M. Gajęcka, K. Kiwerska, M. Rydzanicz, D. Kaczmarczyk, J. Olszewski, K. Szyfter, J. Błasiak, A. Morawiec-Sztandera

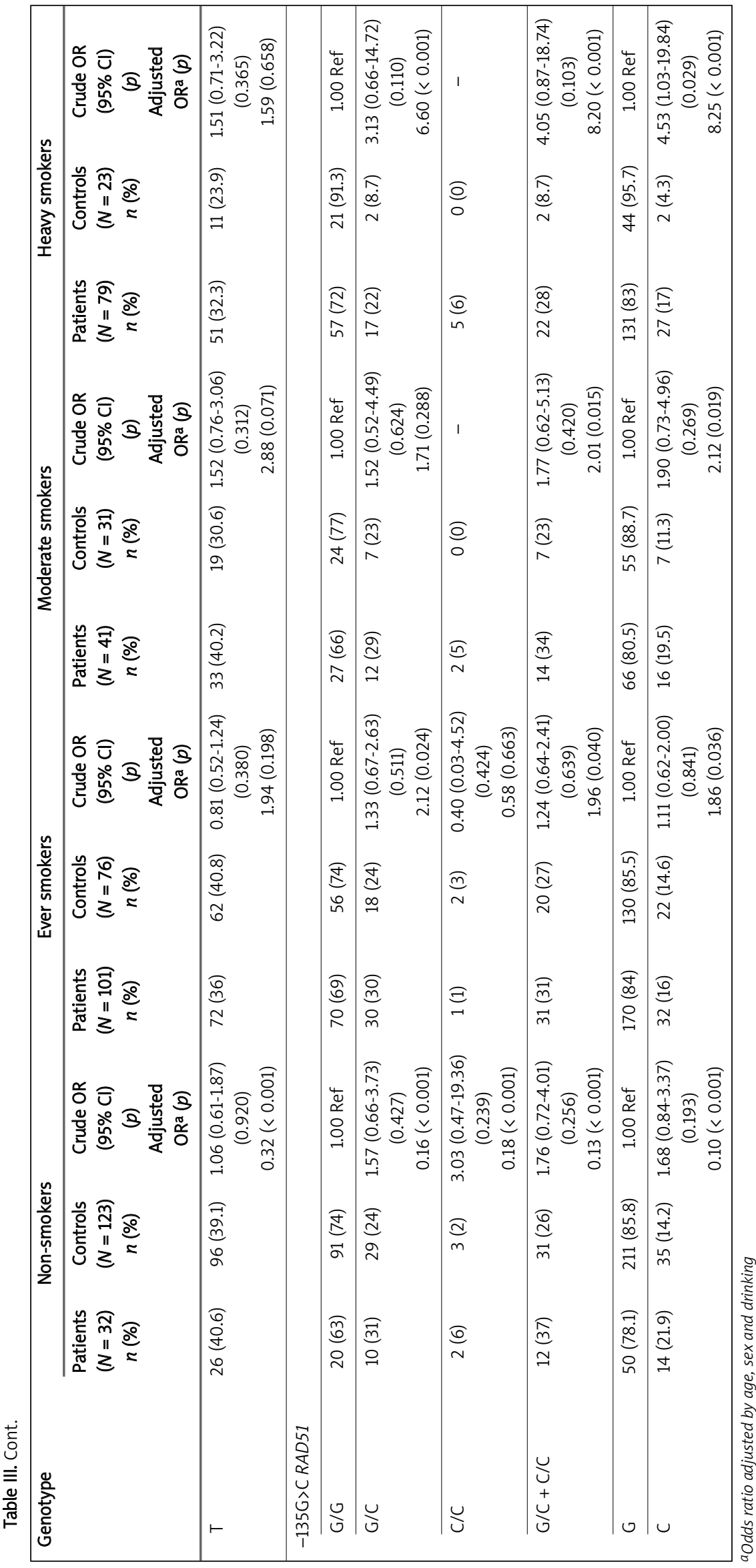




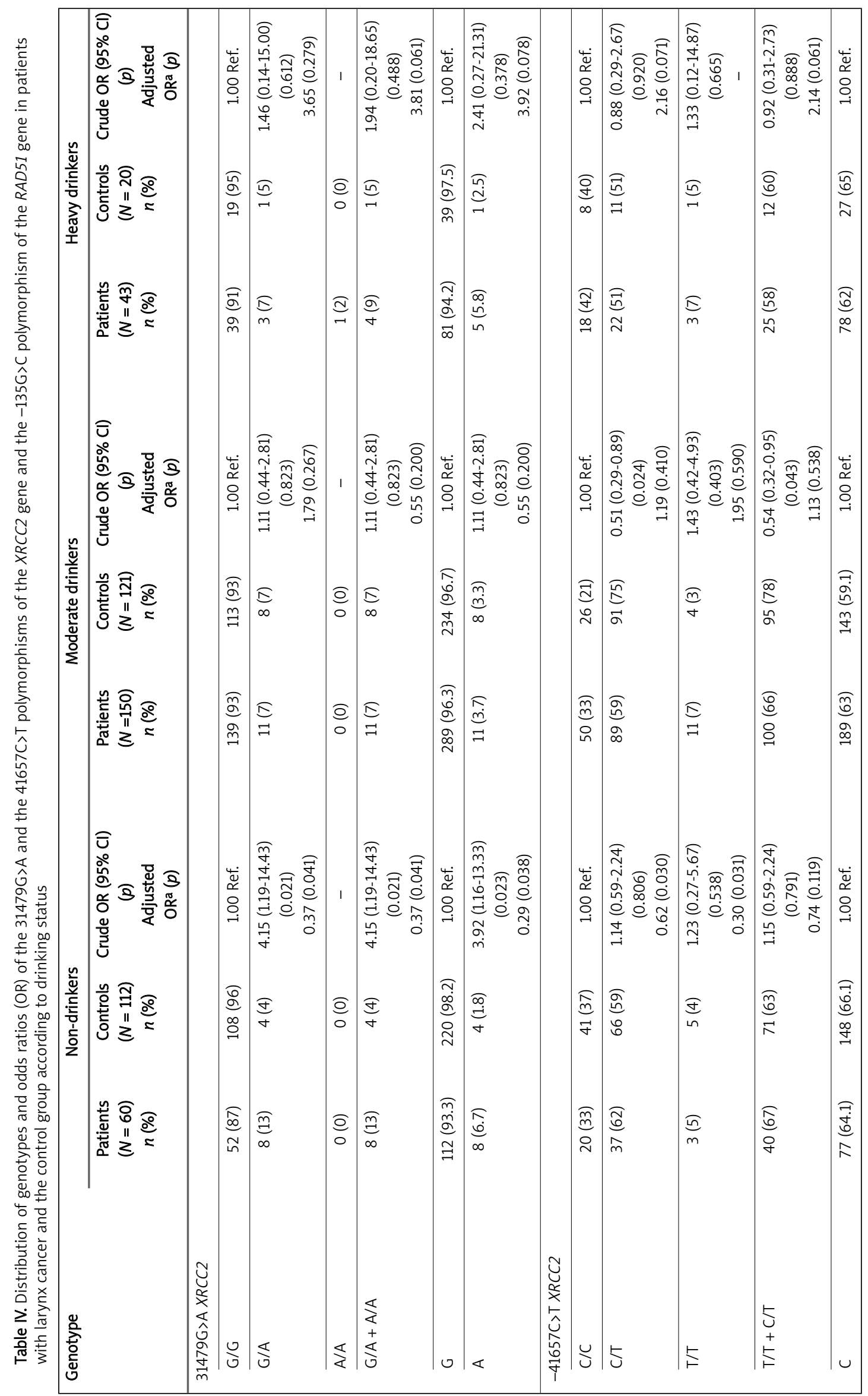


H. Romanowicz-Makowska, B. Smolarz, M. Gajęcka, K. Kiwerska, M. Rydzanicz, D. Kaczmarczyk, J. Olszewski, K. Szyfter, J. Błasiak, A. Morawiec-Sztandera

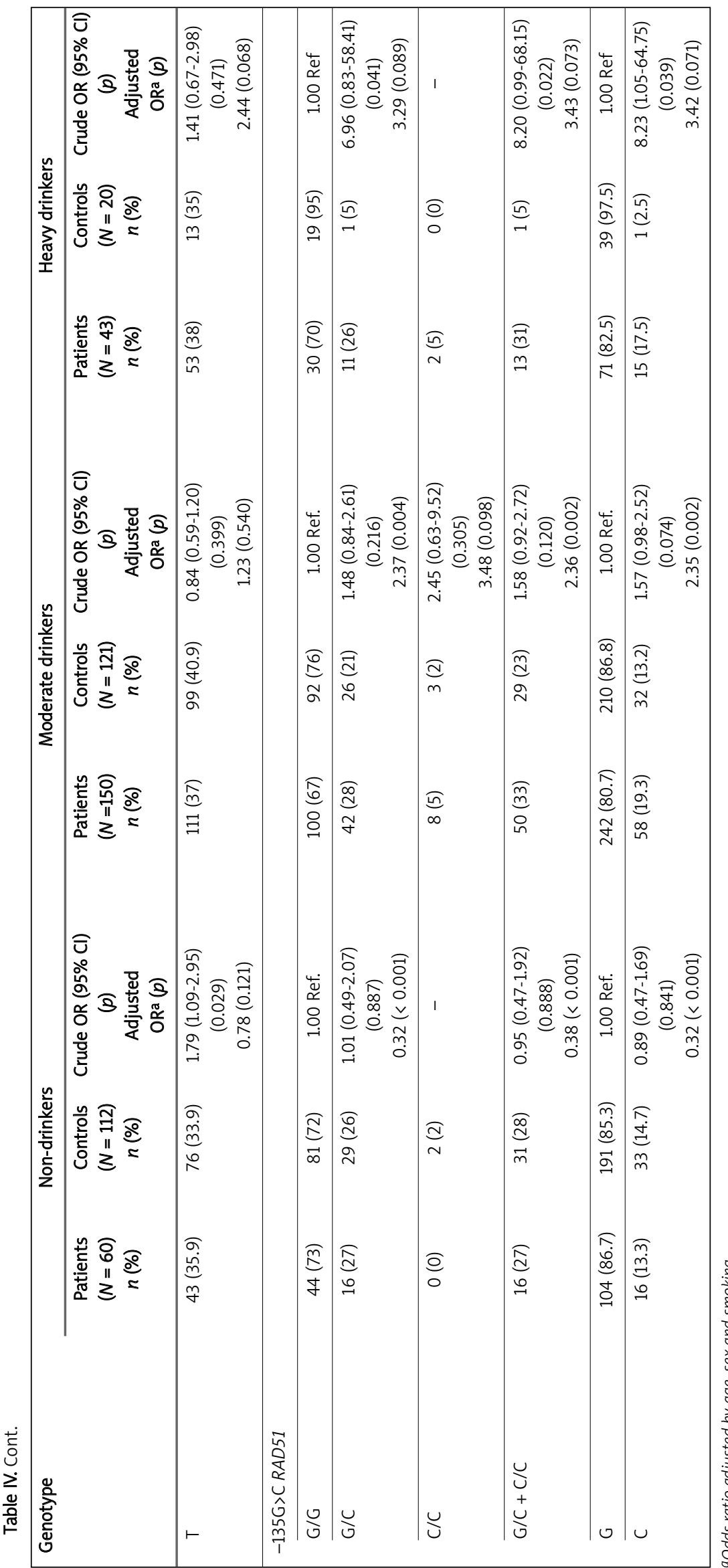


nificance and may be responsible for a low DNA repair capacity phenotype characteristic of cancer patients including larynx carcinoma.

Cancer of the larynx is a head and neck cancer. These include tumors of the nasal cavities, paranasal sinuses, oral cavity, nasopharynx, oropharynx, hypopharynx, and larynx.

The contribution of polymorphisms of various DNA repair genes in development of head and neck carcinoma is controversial.

In the present work we investigated the frequencies of alleles of the XRCC2 $-41657 \mathrm{C}>\mathrm{T}$, $31479 \mathrm{G}>\mathrm{A}$, and RAD51-135G >C polymorphisms in blood from patients with larynx cancer and blood samples from healthy individuals. We investigated the relationship between genotype and the risk for larynx cancer, independent of smoking and drinking. In our study, none of these SNPS was found to individually contribute to larynx cancer risk. We demonstrated that there were no differences in the frequencies of the alleles between patients and controls. We also analyzed the distribution of genotypes and frequency of alleles in groups of patients suffering from larynx cancer according to different cancer staging by the TNM classification. We did not find any association of the $X R C C 2-41657 C>T, 31479 \mathrm{G}>\mathrm{A}$ or $R A D 51$ $-135 \mathrm{G}>C$ polymorphisms in patients with cancer progression assessed by tumor size $(T)$ and node status (N). Our results suggest that these SNPS may not be associated with the occurrence of larynx cancer. At least two concepts can be considered: these polymorphisms are not involved in larynx cancer at all, or they are dependent markers of the disease (gene-gene and gene-environment interactions may modify laryngeal cancer risk). In the second case it is important to find out which factors act in connection with XRCC2 $-41657 \mathrm{C}>\mathrm{T}$, $31479 \mathrm{G}>\mathrm{A}$, and $R A D 51-135 \mathrm{G}>\mathrm{C}$ polymorphisms in larynx cancer. Therefore, as a high risk factor for larynx cancer occurrence we analyzed patients with positive smoking and drinking status within the larynx cancer group.

Our previous results confirm the significance of smoking and alcohol consumption in larynx cancer development. Drinking as well as smoking significantly increased the risk of laryngeal carcinoma in a Polish population [2].

In the reported study, we found an association between RAD51-135G>C and XRCC2 -41657C >T polymorphism and the incidence of drinking-related larynx cancer, but found no significant association with XRCC2 $31479 \mathrm{G}>\mathrm{A}$ polymorphism. Instead, a significant association was identified between RAD51-135G >C polymorphism and smoking-related larynx cancer.

Our results are in agreement with recent data obtained for smoking- and drinking-related laryn- geal cancer in a Polish population [14] and opposed to those obtained by Werobrouck et al. [32], which showed a protective effect of the $-135 \mathrm{G}>\mathrm{C}$ polymorphism on larynx cancer occurrence. On the other hand, a protective effect was obtained in our study for all polymorphisms in the group of never smokers and never drinkers.

Some reports have documented that the XRCC2 $-41657 C>T$ variation was related to increased esophageal squamous cell carcinoma (ESCC) and gastric cardia adenocarcinoma (GCA) risk [24].

This study provides evidence that links $41657 C>T$ polymorphism of the XRCC2 gene with the risk of larynx cancer in moderate drinkers. An increased risk of larynx cancer observed in carriers of heterozygous variants of the $-41657 \mathrm{C}>\mathrm{T}$ polymorphism in a group of moderate drinkers should be interpreted carefully because we did not obtain any association for the T/T homozygotes or for individuals carrying at least one $T$ allele of this polymorphism. This may be due to a small number of variant alleles of this polymorphism obtained for a Polish population.

In our earlier studies we investigated SNPs in base excision repair genes in laryngeal carcinoma. We found that the Cys326 allele of the hOGG1 gene may increase the risk of larynx cancer associated with smoking or alcohol consumption [2]. The Ser/Cys and Cys/Cys genotypes increased the risk of larynx cancer among heavy smokers, but did not change the risk in former smokers or moderate smokers. These genotypes also increased the risk of larynx cancer in moderate and heavy drinkers.

Moreover, we analyzed XRCC2 and RAD51 polymorphisms in breast, endometrial and colorectal cancer [33-37]. Our results suggested that the $135 \mathrm{G}>\mathrm{C}$ polymorphism of the RAD51 gene may be linked to endometrial and colorectal cancer and can be considered as an additional marker of this disease. However, we did not find any association of the $X R C C 2$ polymorphisms with endometrial, breast or colon cancer progression.

Śliwiński et al. examined the role of SNPs in genes that participate in the HR pathway (XRCC3 and RAD51), which repairs double strand DNA breaks and risk of head and neck cancer. The presence of the XRCC3 or RAD51 polymorphic variants allele was associated with the increased risk of cancer progression in smoking and alcohol drinking patients [14].

Flores-Obando et al. found no statistically significant association between smoking, alcohol, human papillomavirus and race/ethnicity and DNA repair gene polymorphisms (XRCC1- base excision repair (BER) and $X P D$ - nucleotide excision repair (NER)) and head and neck cancer [38]. Also, the analysis of a Hungarian population suggested that $X R C C 1$ polymorphism is not correlated with head and neck cancer [39]. 
In contrast, in the Polish population the combined Arg194Trp-Arg399Arg genotype of base excision repair gene $X R C C 1$ may be associated with head and neck cancer and may have an impact on identification of a high-risk cancer population [40].

It is known that polymorphisms in XRCC2 may modify individual susceptibility to smoking-related cancers. Unfortunately, it is difficult to find in the literature reports directly linking SNPs in the DNA repair gene $X R C C 2$ with head and neck cancer occurrence. Only in single studies does the research suggest that potential combination of $X R C C 1$, $X R C C 2, X R C C 3$ and $X R C C 4$ SNPs may have an impact on identification of an oral cancer high-risk population [35]

Benhamou et al. [16] found a correlation between the XRCC2-Arg188His polymorphism and cancers of the upper aerodigestive tract. The XRCC2 188His allele was associated with a significantly increased risk of pharyngeal cancer. The XRCC2 Arg188His polymorphism has been proposed to be a genetic modifier for smoking-related pancreatic cancer [17] and was associated with an increased risk of oral cancer risk [36]. In contrast, Arg188His and three SNPs in the 5' promoter region have been associated with reduced risk of bladder cancer [36].

RAD51 and XRCC2 gene polymorphisms have been studied as a risk factor for various cancers including larynx cancer. In conclusion, the present study provides further evidence for the significance of XRCC2 and RAD51 polymorphism in larynx cancer.

The obtained data suggest that the $-135 \mathrm{G}>\mathrm{C}$ polymorphism in RAD51, involved in the DNA repair pathway, is associated with larynx cancer risk in smoking and drinking patients. Finally, it is postulated that $-135 \mathrm{G}>\mathrm{C}$ polymorphism of the RAD51 gene may be used as a predictive factor for smoking- and drinking-related larynx cancer in Poland. Further studies, conducted on a larger group, are suggested to clarify this point.

\section{References}

1. Parkin DM, Whelan SL, Ferlay J, Teppo L. Cancer incidence in five continents. Vol. VIII. IARC Scientic Publication No. 155. Lyon (France): International Agency for Research on Cancer; 2002.

2. Pawlowska E, Janik-Papis K, Rydzanicz M, et al. The Cys326 allele of the 8-oxoguanine DNA N-glycosylase 1 gene as a risk factor in smoking- and drinking-associated larynx cancer. Tohoku J Exp Med 2009; 219: 269-75.

3. Kupisz K, Stepulak A, Zdunek M, Klatka J. Preliminary results of prognostic significance of proliferating cell nuclear antigen expression in advanced primary larynx carcinomas and lymph node metastases. Arch Med Sci 2010; 6: 65-70.

4. Albino AP, Huang X, Jorgensen E, et al. Induction of H2AX phosphorylation in pulmonary cells by tobacco smoke: a new assay for carcinogens. Cell Cycle 2004; 3: 1062-8.
5. Futreal PA, Liu O, Shattuck-Eidens D, et al. BRCA1 mutations in primary breast and ovarian carcinomas. Science 1994; 266: 120-2.

6. Khanna KK, Jackson SP. DNA double-strand breaks: signaling, repair and the cancer connection. Nat Genet 2001; 27: 247-54.

7. O'Driscoll M, Jeggo PA. The role of double-strand break repair-insights from human genetics. Nat Rev Genet 2006; 7: 45-54.

8. Helleday T. Pathways for mitotic homologous recombination in mammalian cells. Mutat Res 2003; 532: 103-15.

9. Jackson SP. Sensing and repairing DNA double-strand breaks. Carcinogenesis 2002; 23: 687-96.

10. Thacker J. The RAD51 gene family, genetic instability and cancer. Cancer Lett 2005; 219: 125-35.

11. Wang WW, Spurdle $A B$, Kolachana $P$, et al. A single nucleotide polymorphism in the $5^{\prime}$ untranslated region of RAD51 and risk of cancer among BRCA1/2 mutation carriers. Cancer Epidemiol Biomarkers Prev 2001; 10: 955-60.

12. Antoniou AC, Sinilnikova OM, Simard J, et al. RAD51 135G >C modifies breast cancer risk among BRCA2 mutation carriers: results from a combined analysis of 19 studies. Am J Hum Genet 2007; 81: 1186-200.

13. Jakubowska A, Gronwald J, Menkiszak J, et al. The RAD51 $135 \mathrm{G}>\mathrm{C}$ polymorphism modifies breast cancer and ovarian cancer risk in Polish BRCA1 mutation carriers. Cancer Epidemiol Biomarkers Prev 2007; 16: 270-5.

14. Sliwinski T, Walczak A, Przybylowska K, et al. Polymorphisms of the XRCC3 C722T and the RAD51 G135C genes and the risk of head and neck cancer in a Polish population. Exp Mol Pathol 2010; 89: 358-66.

15. Thacker J, Zdzienicka MZ. The XRCC genes: expanding roles in DNA double-strand break repair. DNA Repair 2004; 3: 1081-90.

16. Benhamou S, Tuimala J, Bouchardy C, Dayer P, Sarasin A, Hirvonen A. DNA repair gene XRCC2 and XRCC3 polymorphisms and susceptibility to cancers of the upper aerodigestive tract. Int J Cancer 2004; 112: 901-4.

17. Jiao L, Hassan MM, Bondy ML, et al. XRCC2 and XRCC3 gene polymorphism and risk of pancreatic cancer. Am J Gastroenterol 2008; 103: 360-7.

18. Yen CY, Liu SY, Chen CH, et al. Combinational polymorphisms of four DNA repair genes XRCC1, XRCC2, XRCC3, and XRCC4 and their association with oral cancer in Taiwan. J Oral Pathol Med 2008; 37: 271-7.

19. Han J, Colditz GA, Samson LD, Hunter DJ. Polymorphisms in DNA double-strand break repair genes and skin cancer risk. Cancer Res 2004; 64: 3009-13.

20. Kuschel B, Auranen A, McBride S. Variants in DNA doublestrand break repair genes and breast cancer susceptibility. Hum Mol Genet 2002; 11: 1399-407.

21. Matullo G, Guarrera S, Sacerdote C, et al. Polymorphisms/haplotypes in DNA repair genes and smoking: a bladder cancer case-control study. Cancer Epidemiol Biomarkers Prev 2005; 14: 2569-78.

22. Tranah GJ, Giovannucci E, Ma J, Fuchs C, Hankinson SE, Hunter DJ. XRCC2 and XRCC3 polymorphisms are not associated with risk of colorectal adenoma. Cancer Epidemiol Biomarkers Prev 2004; 13: 1090-1.

23. Sliwinski T, Krupa R, Majsterek I, et al. Polymorphisms of the BRCA2 and RAD51 genes in breast cancer. Breast Cancer Res Treat 2005; 94: 105-9.

24. Wang N, Dong XJ, Zhou RM, Guo W, Zhang XJ, Li Y. An investigation on the polymorphisms of two DNA repair genes and susceptibility to ESCC and GCA of high- 
incidence region in northern China. Mol Biol Rep 2009; 36: 357-64.

25. Vineis P, Talaska G, Malaveille C, et al. DNA adducts in urothelial cells: relationship with biomarkers of exposure to arylamines and polycyclic aromatic hydrocarbons from tobacco smoke. Int J Cancer 1996; 65: 314-6.

26. Asami S, Manabe H, Miyake J, et al. Cigarette smoking induces an increase in oxidative DNA damage, 8-hydroxydeoxyguanosine, in a central site of the human lung. Carcinogenesis 1997; 18: 1763-6.

27. Loft S, Deng XS, Tuo J, Wellejus A, Sørensen M, Poulsen $\mathrm{HE}$. Experimental study of oxidative DNA damage. Free Radic Res 1998; 29: 525-39.

28. Wiencke JK. DNA adduct burden and tobacco carcinogenesis. Oncogene 2002; 21: 7376-91.

29. Guo R, Ren J. Alcohol and acetaldehyde in public health: from marvel to menace. Int J Environ Res Public Health 2010; 7: 1285-301.

30. Rulten SL, Hodder E, Ripley TL, Stephens DN, Mayne LV. Alcohol induces DNA damage and the Fanconi anemia D2 protein implicating FANCD2 in the DNA damage response pathways in brain. Alcohol Clin Exp Res 2008; 32: 1186-96.

31. Pöschl G, Seitz HK. Alcohol and cancer. Alcohol Alcohol 2004; 39: 155-65.

32. Werbrouck J, De Ruyck K, Duprez F, et al. Single-nucleotide polymorphisms in DNA double-strand break repair genes: association with head and neck cancer and interaction with tobacco use and alcohol consumption. Mutat Res 2008; 656: 74-81.

33. Romanowicz H, Smolarz B, Baszczyński J, Zadrożny M, Kulig A. Genetics polymorphism in DNA repair genes by base excision repair pathway (XRCC1) and homologous recombination (XRCC2 and RAD51) and the risk of breast carcinoma in the Polish population. Pol J Pathol 2010; 61: 206-16.

34. Krupa R, Sliwinski T, Wisniewska-Jarosinska $M$, et al. Polymorphisms in RAD51, XRCC2 and XRCC3 genes of the homologous recombination repair in colorectal cancer-a case control study. Mol Biol Rep 2011; 38: 2849-54.

35. Yen CY, Liu SY, Chen CH. Combinational polymorphisms of four DNA repair genes XRCC1, XRCC2, XRCC3, and XRCC4 and their association with oral cancer in Taiwan. J Oral Pathol Med 2008; 37: 271-7.

36. Yen CY, Liu SY, Chen CH. Evaluation of genetic variation in the double-strand break repair pathway and bladder cancer risk. Carcinogenesis 2007; 28: 1788-93.

37. Krupa R, Sobczuk A, Popławski T, Wozniak K, Blasiak J. DNA damage and repair in endometrial cancer in correlation with the hOGG1 and RAD51 genes polymorphism. Mol Biol Rep 2011; 38: 1163-70.

38. Flores-Obando RE, Gollin SM, Ragin CC. Polymorphisms in DNA damage response genes and head and neck cancer risk. Biomarkers 2010; 15: 379-99.

39. Csejtei A, Tibold A, Koltai K, et al. Association between XRCC1 polymorphisms and head and neck cancer in a Hungarian population. Anticancer Res 2009; 29: 4169-73.

40. Kowalski M, Przybylowska K, Rusin P, et al. Genetic polymorphisms in DNA base excision repair gene XRCC1 and the risk of squamous cell carcinoma of the head and neck. J Exp Clin Cancer Res 2009; 13: 28-37. 